UDC 330.332 .5

JEL Classification: G320; Q14; M20

DOI: https://doi.org/10.32317/2221-1055.201912097

Yu.O. SIVITSKA, PhD student*

\title{
Specificity of the discount rate application for agricultural business valuation
}

The purpose of the article is to determine which method of beta coefficient calculation for agricultural companies gives the most correct result. The article also describes the peculiarities, problematic issues and ways of their solution that arise during the calculation of an agricultural company discount rate in the process of business valuation.

Research methods. The study was conducted on the example of agricultural holdings IMC S.A. and Astarta Holding N.V., listed on the Warsaw Stock Exchange (WSE). The beta coefficients of agroholdings were calculated by various methods and the data used to determine the value of the agricultural business by an income methodological approach, a discounted cash flow method.

Research results. The necessity of calculating company beta instead of using pre-calculated industry beta coefficients of agricultural company from different sources in business valuation for the investment purpose has been proved. The obtained results indicate that methodology, which substantiated in the article provides $a$ value of one company's share as close as possible to its current quotation on the Warsaw Stock Exchange.

Elements of scientific novelty. The statement that the use of pre-calculated beta coefficients leads in distorting the result of business valuation was further developed. This article provides a rationale for calculating all the components of the Build-up method modified formula to calculate the discount rate of agricultural companies in the process of business valuation for investment purposes for the first time.

Practical significance. The results of this research will be useful for valuation specialists (professional appraisers) during the calculation of the discount rate for agricultural business valuation for investment purposes. Tabl.: 8. Figs.: 8 . Refs.: 25.

Keywords: discount rate; beta companies; business valuation; risk-free rate; equity risk premium; build-up method modified.

Sivitska Yuliia Oleksandrivna - PhD student of the department of entrepreneurship and law, Poltava State Agrarian Academy $(1 / 3$, Skovorody st., Poltava)

E-mail: ijosjo@ukr.net

ORCID iD https://orcid.org/0000-0001-8635-9038

Scientific problem. The most complex, controversial and influential component in calculating the discount rate with the Build-up method modified is beta coefficient. Different methods of calculation lead to different results. Therefore, there is a need to identify which of the methods provides the most realistic result of an agricultural business value.

Analysis of recent research and publications. Previously unsolved part of the problem: the methodology of calculating beta coefficient for agricultural business valuation for the investment purposes.

By formulating a Capital Asset Pricing Model (CAPM), Sharpe (Sharpe, 1964) determined that a beta coefficient $(B)$ is an unsystematic risk, which is the only risk indicator

\footnotetext{
* Scientific supervisor - Kh.Z. Makhmudov, doctor of economic sciences, professor.

(c) Yu.O. Sivitska, 2019
}

that explains return on securities. As for the discount rate, it can be used to assess the risk of the investment project realisation [1].

Cea (Cea, 1979) argued: that if all risks, inherent in project are included in the discount rate then its magnitude, in opinion of all the participants of the project, should be the same [2].

Caballer-Mellado and Moya-Clemente (Caballer-Mellado \& Moya-Clemente, 1998) stated in their article: using the discounted cash flows method means applying suggestions about the initial parameters, on which business value depends. Accuracy is a determinant factor in this case, because the value of the business is very sensitive to the magnitude of the discount rate [3].

Tabak (Tabak, 2002) proposed a theoretical model based on CAPM, which allows us to estimate the illiquidity discounts on the basis of the objective criteria. This model on an equi- 
ty risk premium base is a first approach, which applies CAPM to the process of illiquidity discounts calculation [4].

Holton (Holton, 2004) explored a nature of risk, scince this term is very controvercial and, at the same time, is widely used. Holton noted, that it is impossible to calculate the risk operationally, and, as practising financiers, we can compute our subjective perception of risk only. Because risk is a relative concept, associated with an individual investor [5].

Fernandes (Fernández, 2008) noted that in business valuation, determining the discount rate is one of the most important issues, which is carried out taking into account risk and historical volatility [6].

Koval (Koval, 2010) analyzed the existing methods of calculating the discount rate and developed recommendations that will help to increase its objectivity [7].

Kolchar (Kolchar, 2013) analysed the practical expediency of applying CAPM for the bank's equity valuation and revealed the models of bank's equity value calculation which are optimal [8].

Ralko (Ralko, 2015) analyzed and systematized all existing domestic and foreign methodology of the discount rate calculation, described the advantages and disadvantages of using them in modern economic conditions [9].

Fernández et al. (Fernández et al., 2017) conducted research on the risk-free rate and the market risk premium used in 2017 in 41 countries [10].

The purpose of the article is to determine which method of beta coefficient calculation for agricultural companies gives the most correct result. The article also describes the peculiarities, problematic issues and ways of their solution that arise during the calculation of an agricultural company discount rate in the process of business valuation

Research methodology. The study was conducted on the example of agricultural holdings IMC S.A. and Astarta Holding N.V., listed on the Warsaw Stock Exchange (WSE). The beta coefficients of agroholdings were calculated by various methods and the data used to determine the value of agricultural business by an income methodological approach, a discounted cash flow method.

Research results. The discount rate, used in company valuation process is very important for investors: it is the profit that they expect in the future. A higher discount rate means a higher expected return and, at the same time, a higher risk, a lower - respectively a lower.

Determining the discount rate is one of the most important tasks and takes into account the risk of historical fluctuations. In practice, the minimum discount rate is often set by stakeholders (buyers or sellers are not ready to invest or sell for less profit).

In company valuation, based on the discounted cash flow method, there is a need to determine the appropriate discount rate for each type of cash flow [11, p.27-28].

The Build-up method is actually expanded or supplemented CAPM method.

According to the CAPM method, the discount rate consists of RFR (risk-free rate) plus ERP (equity risk premium) multiplied by the company beta. Theorists have suggested that industry betas are more reliable than the beta calculated for an individual company (company beta). Ibbotson et al noted that the result of using the CAPM method is too high for a company with large market cap, and too low for company with small. It is suggested to add a size premium (CSP) to the discount rate calculated by the Build-up method. Thus, the formula of the modified CAPM method consists of RFR plus ERP multiplied by an industry beta plus size premium [12, p.38].

Then the modified CAPM method essentially becomes a Build-up method, except that the specific risk of the company (Specific Company Risk Premium, SCRP) is diversified in the CAPM method, but it is explicitly included in a Build-up method as a company specific risk premium (SCRP).

If we look at it this way, then the Build-up method is a modified CAPM with a company specific risk premium (SCRP) added:

$$
\mathrm{Ke}=\mathrm{R} f+\mathrm{B} i \cdot \mathrm{ERP}+\mathrm{SCRP}+\mathrm{CSP},
$$

Ke - discount rate; $R f$ - risk free rate; Bi - industry beta; ERP - equity risk premium; SCRP - specific company risk premium; CSP - size premium [12, p. 38].

In our calculations we have replaced the industry beta with the company beta, calculated according to Fernández and Carabias (Fernández P. \& Carabias Jose M., 2007), which substantiates that the use of historical beta leads to significant errors in business valuation.

In the following, we consider separately all the components of this formula, controversial 
questions about them, and the problems that arise in the calculation process.

Problems in equity risk premium (EPR) calculation

Equity risk premium (ERP) is an important element of both the CAPM and the Build-up method for calculating the discount rate. Determining the equity risk premium (EPR) is the source of the highest number of errors in business valuation (including calculation of the cost of capital) [12, p.41].

Equity risk premium (also referred to as market risk premium, equity risk premium, market premium and risk premium) is one of the most important and widely discussed, but inaccurate parameters in finance. Part of the confusion arises because the term "equity risk premium" is used to refer to four different concepts:

- Historical equity premium (HEP): historical differential return on stock market over income on government securities;

- Expected equity premium (EEP): expected differential return on government securities;

- Required equity premium (REP): the additional return on a diversified portfolio (market premium) over the risk-free rate that an investor expects. It is used to calculate the required rate of return on equity;

- Implied equity premium (IEP): the required equity risk premium that arises from the assumption that the market price is correct [13, p. 4].

\section{lation}

Problems in the risk-free rate (RFR) calcu-

When choosing a risk- free rate (RFR) for business valuation purposes, we may face the following issues:

The risk-free rate - the theoretical rate of return on investment with zero risk, which is used in finance, including expected inflation (nominal yield). If a nominal RFR is used, the appraiser should use future cash flows that are nominal (i.e. reflect future inflation). If real RFR is used, then real future cash flows should be used [12, p. 38-39].

Another problem is that the risk-free of government securities of any country today is in doubt. In principle, RFR is the minimum rate of return that an investor expects to receive before making a risky investment, since no investor will accept the risk if the potential rate of return is less than the risk-free rate. However, the risk-free rate was negative in the US in 2008 and again in Germany in 2011-2012 [12, p. 39].

If your current RFR does reflect a temporary perception of the riskiness of other investments, then adding a historical ERP to your current RFR will lower the discount rate and overestimate your business more than it actually is today.

When confronted with such a situation, the international consulting firm Duff \& Phelps "normalize" the risk-free rate used to calculate ERP, for example, according to the average rate over the past 12 months. Treasury yields in a particular country are sometimes used by finance professors as a risk-free rate. Their reliability is questionable to serve as a basis for long-term investment decisions. Some researchers use a 5-year US Treasury bond rate, and professional appraisers often use a 10,20 or 30-year risk-free rate of return [12, p. 40].

The risk-free rate for all countries should not be chosen solely on government bond yields, as there are others, substantiated and implemented into the valuation practice alternatives to government securities. The situation of each country must be considered separately.

\section{tion \\ Problems in the beta coefficient calcula-}

The only specific input in valuing of a company by the CAPM method is the beta coefficient. Understanding the beta coefficient is important for making a large number of decisions about a company's business, including calculating the cost of equity to evaluate corporate projects, risk adjustments, portfolio risk measurement and even litigation, related to government securities, where market efficiency or losses should be assessed [14, p. 2].

Beta coefficients, published in different investment services differ. One reason for this is that these services use different inputs to build the beta. The other is that these services make different adjustments to their beta calculations, pursuing different concepts of accuracy [12, p. 48].

It is a serious mistake to use beta coefficients, calculated on the basis of historical data to calculate the required return on shares or securities portfolio management. For seven reasons:

- beta coefficients calculated from historical data vary greatly from day to day; 
- since the calculated beta coefficients depend on stock index, taken as a benchmark;

- beta coefficients are very dependent on what historical period ( 5 years, 3 years, etc.) is used to calculate them;

- computed beta depends on what profitability (monthly, annual and others) is used to calculate them;

- very often we do not know whether the beta of a given company is higher or lower than for another company in the same sector;

- computed beta coefficients are very weakly associated with further stock returns;

- the correlation (and parameter value R2) of the regressions which used to calculate beta is very small [15, p. 4].

For these seven reasons we can state that:

- a beta computed from historical data is not a good calculation of a company beta;

- CAPM does not work (there are more factors that affect the required profitability of a company, in addition to covariating a company's profitability with market profitability, risk-free rate and market risk premium);

- the practical implication of this study of beta coefficients is that the use of historical beta in company valuation without analyzing it the future prospects is very risky (and is usually a source of serious errors) $[15$, p. 5].

We have calculated the historical beta of the IMC S.A. and Astarta Holding N.V. according to the methodology of Fama and MacBeth [16] and to the formula:

$$
\text { Beta }=\frac{\text { Covariance }(\mathrm{Re}, \mathrm{Rm})}{\text { Variance }(\mathrm{Rm})}
$$

$\mathrm{Re}$ - profitability of the given security; Rm - the market yield or the yield of the stock index, which is taken as the benchmark [16, p. 600].

Because, the most basic approach to beta calculation is simply to estimate covariance parameters in the time series of historical returns on securities [17, p. 1438].

The S\&P Global agricultural index is used as a market indicator (benchmark) [18].

The stock exchange data of the companies was obtained from the website of the Warsaw Stock Exchange [19].

We gathered the necessary data and calculated beta coefficients according the market data (Warsaw Stock Exchange) for the annual period (with weekly sampling period) on the example of IMC S.A. (see Figures 3,4) and Astarta Holding N.V. (see Figures 1, 2).

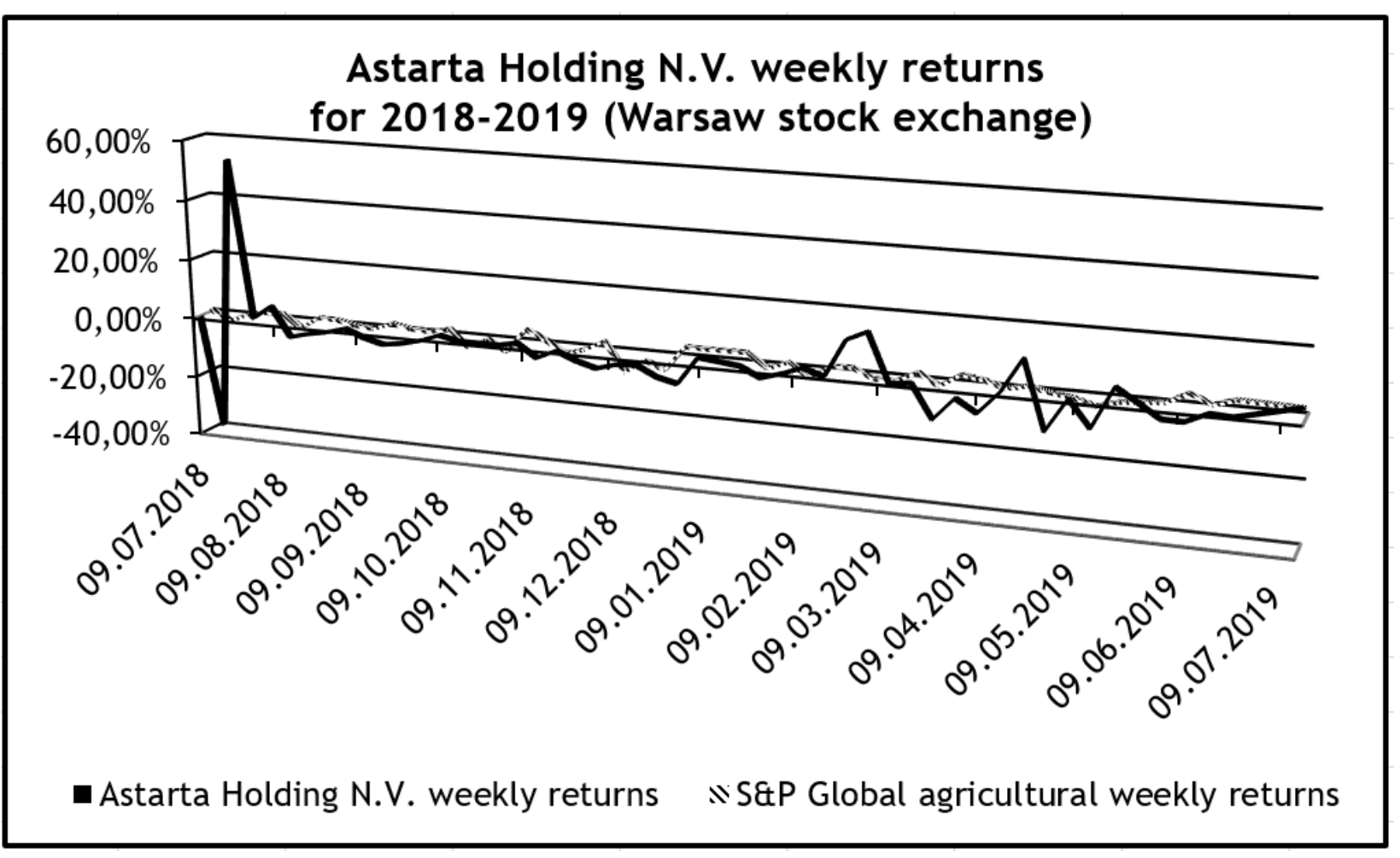

Figure 1. Astarta Holding N.V. weekly returns for 2018-2019

Source: Own elaboration. 


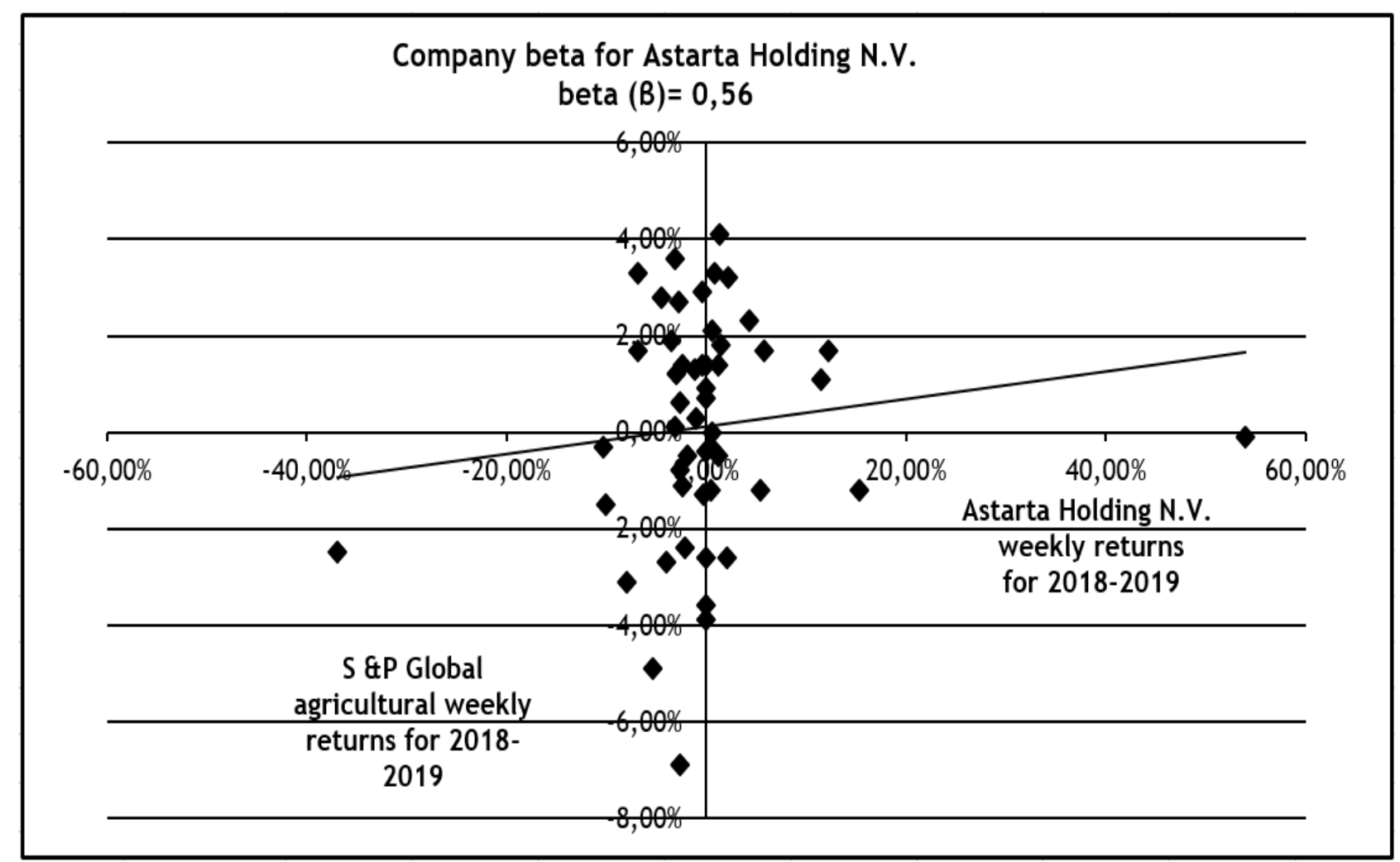

Figure 2. Company beta for Astarta Holding N.V.

Source: Own elaboration based on [16].

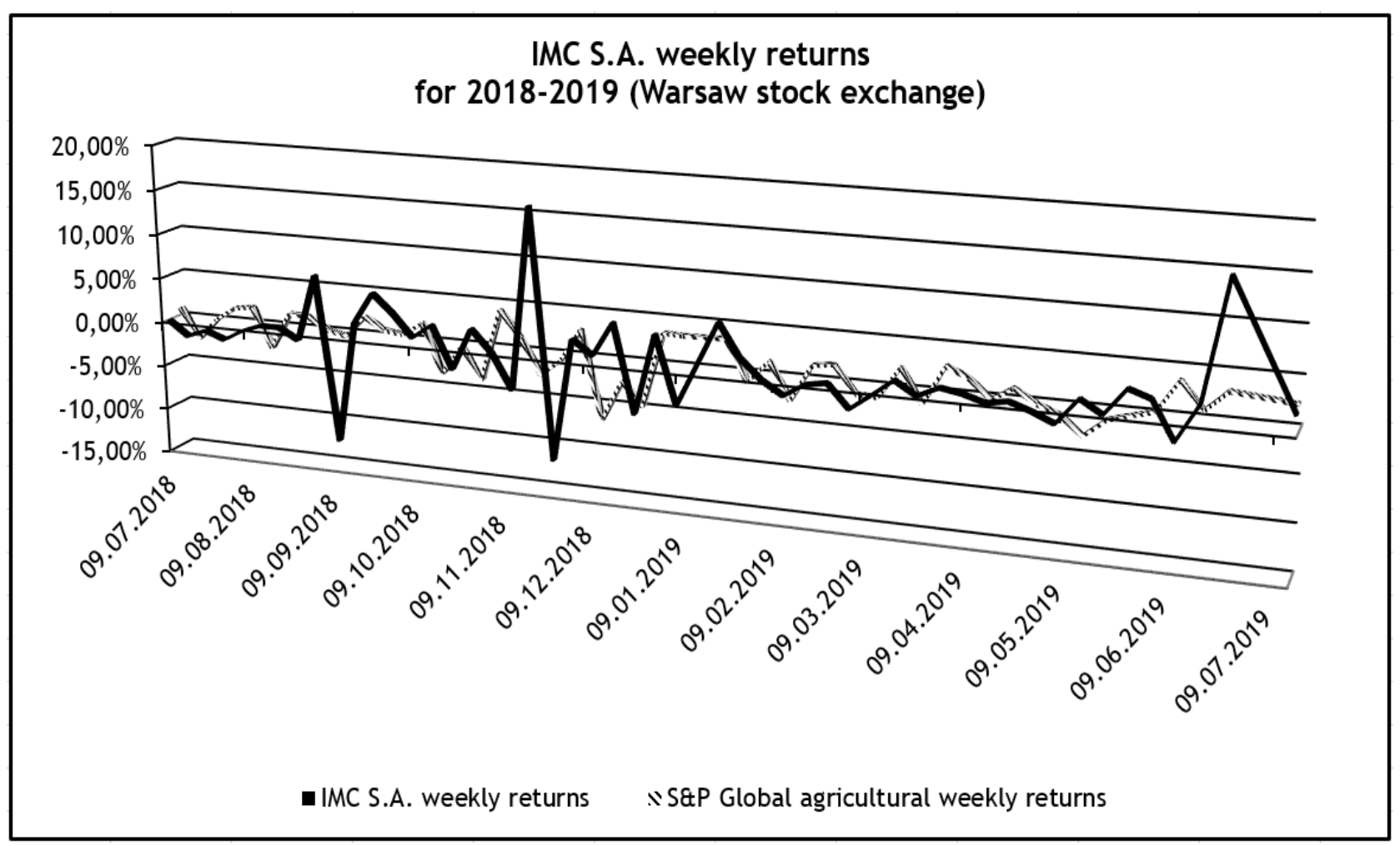

Figure 3. IMC S.A. weekly returns for 2018-2019

Source: Own elaboration. 


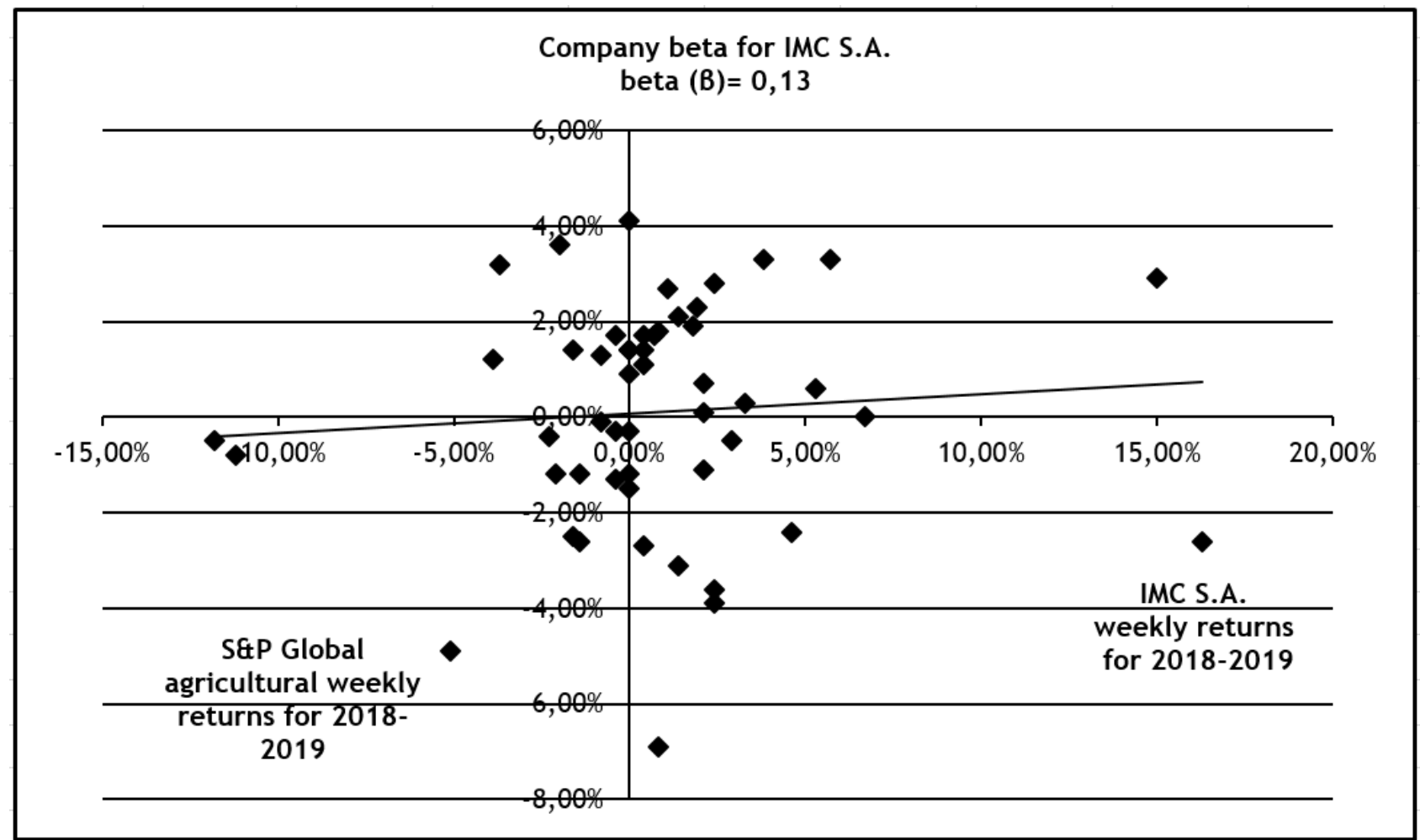

Figure 4. Company beta for IMC S.A.

Source: Own elaboration based on [16].

We gathered the necessary data and calculated beta coefficients according the market data (Warsaw Stock Exchange) for the annual

period (with monthly sampling period) on the example of IMC S.A. (see Figures 5,6 ) and Astarta Holding N.V. (see Figures 7, 8).

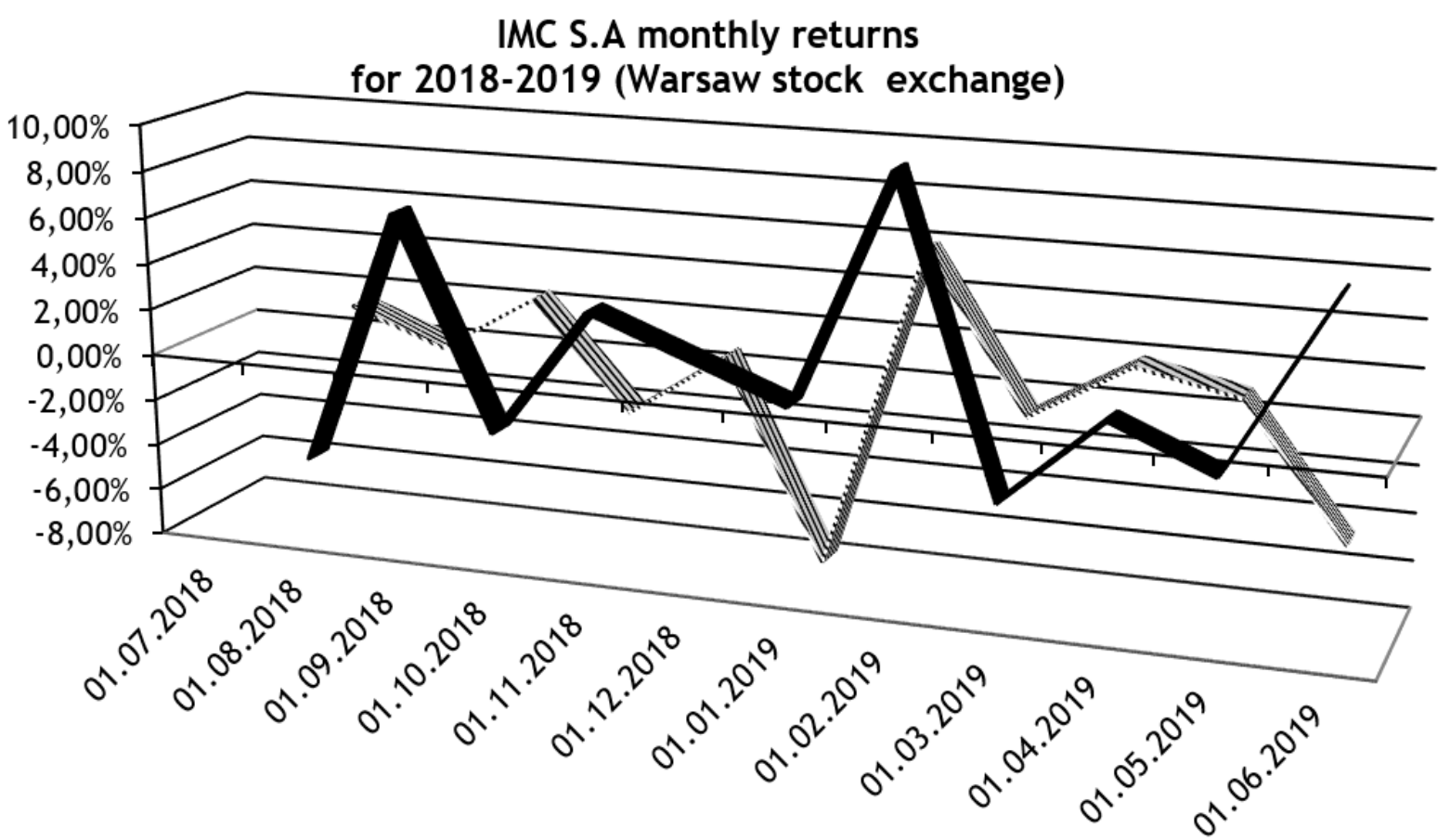

- IMC S.A. monthly returns

s S\&P Global agricultural monthly returns

Figure 5. IMC S.A. monthly returns for 2018-2019

Source: Own elaboration. 


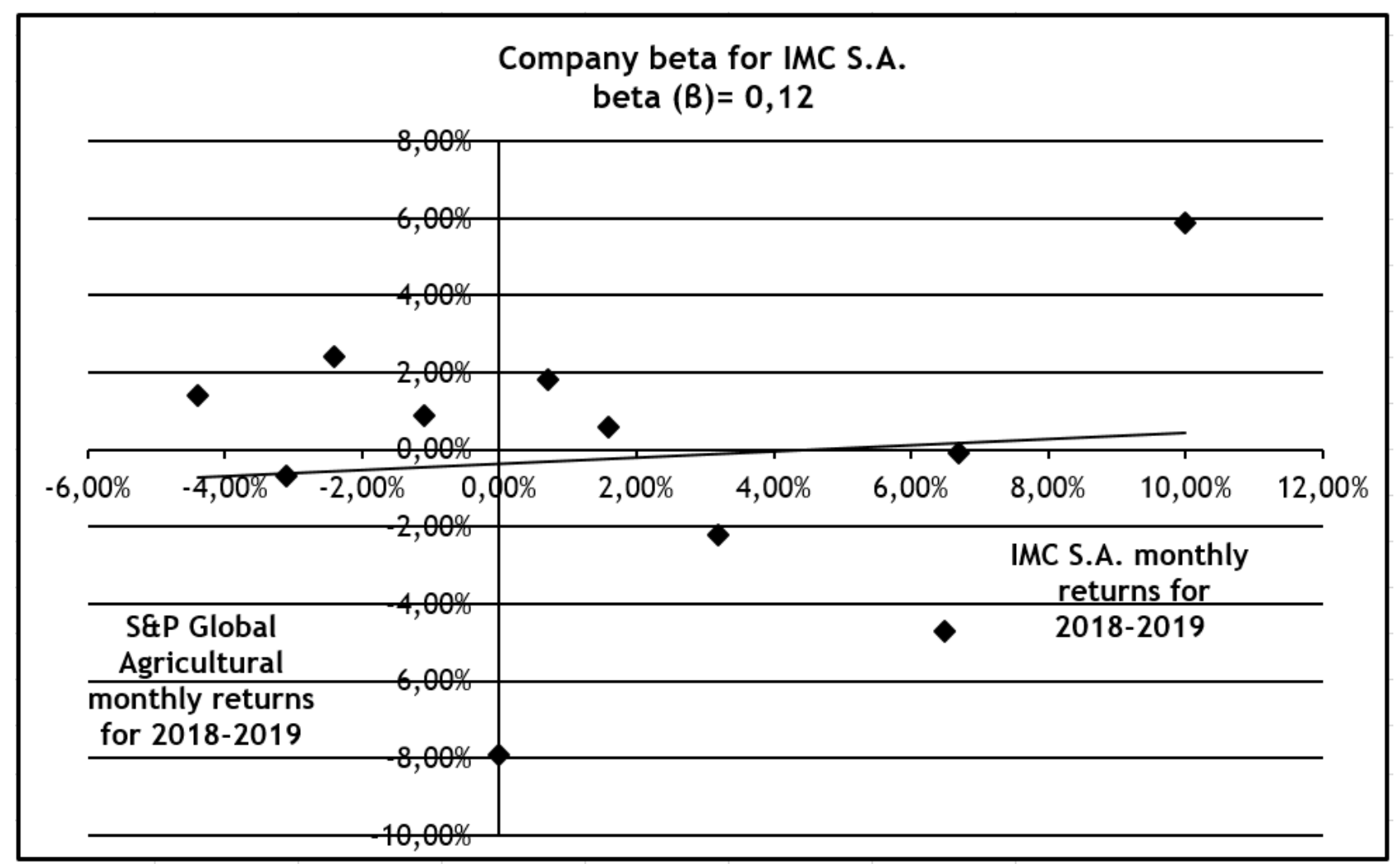

Figure 6. Company beta for IMC S.A.

Source: Own elaboration based on [16].

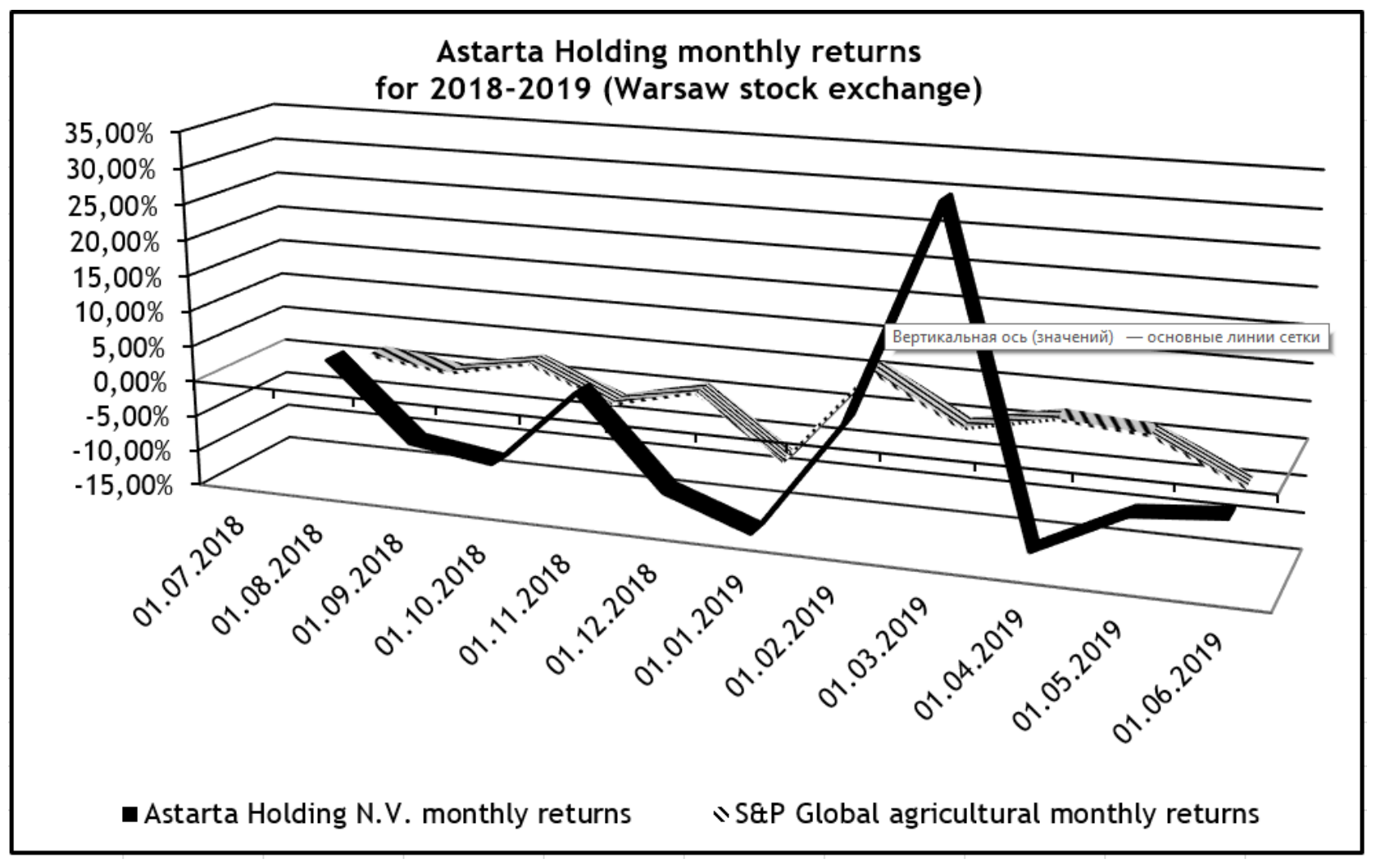

Figure 7. Astarta Holding N.V. monthly returns for 2018-2019

Source: Own elaboration. 


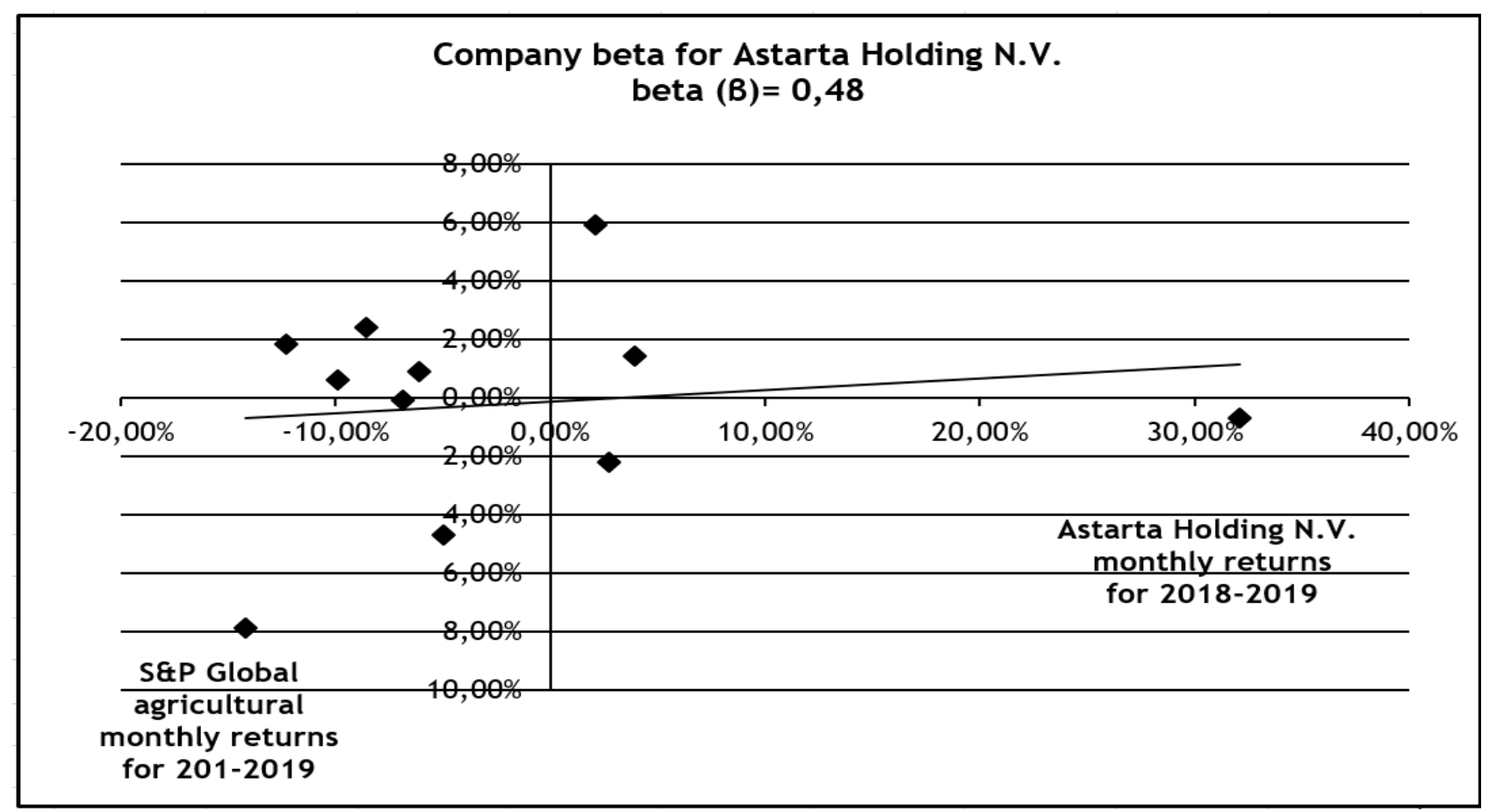

Figure 8. Company beta for Astarta Holding N.V.

Source: Own elaboration based on [16].

Given the instability of beta coefficient, as such, low reliability of the beta, calculated on the basis of historical data many companies are looking for a quality beta calculation methodology.

The NODERFELASE method (an abbreviation of the parameter's initials that are taken to estimate the risk of the project) to determine the beta. Each parameter is rated from 1 to 5 points according to its weight in the overall risk. It is also necessary to determine the weight of each factor. The points of all the parameters are added and the value of company beta is calculated according to their weight. Other alternatives to the NODERFELASE method are: the MARTILLO method and the NADEFLEX method. The investment firm Goldman Sachs recommends the CAMEL method: C (Capital); A (Asset quality refers to business risk); $M$ (Management); E (Earnings refers to earnings volatility) and $L$ (Liquidity means stock liquidity) [15, p. 14-15].
Fernández describes several of these methods, named according to initials of the parameters used to evaluate the risk of each project:

- MASCOFLAPEC (management, assets, strategy, country risk, operating leverage, financial leverage, liquidity of investment, access to sources of funds, partners, exposure to other risks and cash flow stability);

- MARTILLO (management, asset quality, risk exposure, trade analysis, product/market, IRR of new investments, leverage, liquidity and other relevant factors);

- BAMIFLEX (business, product/demand/ market, access to credit, management, indebtedness, flows, liquidity, exposure to other risks) [15, p. 15-16].

Table 1 and Table 2 provide an example of the calculation of IMC S.A. and Astarta Holding N.V. company betas with the NODERFELASE method.

Table 1. IMC S.A. company beta calculation with the NODERFELASE method

\begin{tabular}{|c|c|c|c|c|c|c|c|c|}
\hline Weighing & & Factors & \multicolumn{5}{|c|}{ Risk } & Weighted risk \\
\hline & & & 1 & 2 & 3 & 4 & 5 & \\
\hline $25 \%$ & $\mathbf{N}$ & $\begin{array}{l}\text { Business, } \\
\text { sector, } \\
\text { product }\end{array}$ & & & 3 & & & 0,75 \\
\hline $10 \%$ & 0 & Operating leverage & & & & 4 & & 0,4 \\
\hline $10 \%$ & D & Management & & & & 4 & & 0,4 \\
\hline $5 \%$ & $\mathrm{E}$ & $\begin{array}{l}\text { Exposure to other } \\
\text { risks }\end{array}$ & & & 3 & & & 0,15 \\
\hline
\end{tabular}


continuation table 1

\begin{tabular}{|c|c|c|c|c|c|c|}
\hline $15 \%$ & $\mathbf{R}$ & Country risk & & & 4 & 0,6 \\
\hline $5 \%$ & $\mathbf{F}$ & Cash flow stability & & 3 & & 0,15 \\
\hline $15 \%$ & $\mathbf{E}$ & Indebtedness & & & 4 & 0,6 \\
\hline $5 \%$ & $\mathbf{L}$ & $\begin{array}{l}\text { Liquidity of } \\
\text { investment }\end{array}$ & & 3 & & 0,15 \\
\hline $5 \%$ & A & $\begin{array}{c}\text { Access to sources } \\
\text { (funds) }\end{array}$ & & & 4 & 0,2 \\
\hline $2 \%$ & $\mathbf{S}$ & Partners & 2 & & & 0,04 \\
\hline $3 \%$ & $\mathbf{E}$ & Strategy & & 3 & & 0,09 \\
\hline $100 \%$ & & \multicolumn{4}{|c|}{ Beta of own resources $=3,53 \times 0,5=1,765$} & 3,53 \\
\hline
\end{tabular}

Source: Own elaboration based on [15].

Table 2. Astarta Holding N.V. company beta calculation with the NODERFELASE method

\begin{tabular}{|c|c|c|c|c|c|c|c|c|}
\hline \multirow[t]{2}{*}{ Weighing } & & \multirow[t]{2}{*}{ Factors } & \multicolumn{5}{|c|}{ Risk } & \multirow{2}{*}{$\begin{array}{l}\text { Weighted } \\
\text { risk }\end{array}$} \\
\hline & & & 1 & 2 & 3 & 4 & 5 & \\
\hline $25 \%$ & $\mathbf{N}$ & $\begin{array}{l}\text { Business, } \\
\text { sector, } \\
\text { product }\end{array}$ & & & 3 & & & 0,75 \\
\hline $10 \%$ & 0 & $\begin{array}{l}\text { Operating } \\
\text { leverage }\end{array}$ & & & 3 & & & 0,3 \\
\hline $10 \%$ & D & Management & 1 & & & & & 0,1 \\
\hline $5 \%$ & $E$ & $\begin{array}{l}\text { Exposure to } \\
\text { other risks }\end{array}$ & & & 3 & & & 0,15 \\
\hline $15 \%$ & $\mathbf{R}$ & Country risk & & & & 4 & & 0,6 \\
\hline $5 \%$ & $\mathbf{F}$ & $\begin{array}{l}\text { Cash flow } \\
\text { stability }\end{array}$ & & 2 & & & & 0,1 \\
\hline $15 \%$ & $E$ & Indebtedness & 1 & & & & & 0,15 \\
\hline $5 \%$ & $L$ & $\begin{array}{l}\text { Liquidity of } \\
\text { investment }\end{array}$ & & 2 & & & & 0,1 \\
\hline $5 \%$ & A & $\begin{array}{l}\text { Access to sources } \\
\text { (funds) }\end{array}$ & & 2 & & & & 0,1 \\
\hline $2 \%$ & $\mathrm{~S}$ & Partners & 1 & & & & & 0,02 \\
\hline $3 \%$ & $E$ & Strategy & & 2 & & & & 0,06 \\
\hline $100 \%$ & & Beta of & . & ces & ה & ,2 & & 2,43 \\
\hline
\end{tabular}

Source: Own elaboration based on [15].

Further, to identify which method of company beta calculation gives the most correct result in agricultural business valuation, we computed the value of IMC S.A. and Astarta Holding N.V. with income approach, discounted cash flow method.

To calculate the discount in the process of agricultural business valuation for the investment purpose, based on a preliminary study [20], we used build-up method.

The business valuation of both agroholdings was carried out on the basis of the financial statements for the previous years 2014-2018, presented on the official websites of the companies: IMC S.A. [21] and Astarta Holding N.V. [22].

We calculated discount rates (Table 3) using the different company betas for Astarta Holding N.V., obtained by us from the above calculations.

Next, we calculated the company value of Astarta Holding N.V using an income approach, discounted cash flow method (see Table 4) at a discount rate - $21.87 \%$. The cash flow forecast is based on the simple average value of the operating cash flow over the past 5 years (2014-2018) with a 5\% annual growth rate. 
Table 3. Astarta Holding N.V.: discount rates calculation using different company betas

\begin{tabular}{|c|c|c|c|c|c|}
\hline Parameter & 2019 & Abbreviation & Comments & Formula* & $\begin{array}{l}\text { Discount } \\
\text { rate }\end{array}$ \\
\hline Risk free rate & 1,9 & RFR & $\begin{array}{l}\text { The average rate on } \\
\text { deposits of legal } \\
\text { entities in foreign } \\
\text { currency in Ukraine } \\
5,5 \% \text {; [23] } \\
\text { Inflation rate (2019) } \\
3,6 \% ;[24]\end{array}$ & & \\
\hline $\begin{array}{l}\text { Equity risk } \\
\text { premium }\end{array}$ & 16,37 & ERP & $\begin{array}{l}\text { The average equity } \\
\text { risk premium for } \\
\text { Ukraine } \\
\text { (Damodaran) [25] }\end{array}$ & & \\
\hline $\begin{array}{l}\text { Industry beta } \\
\text { (Farming and } \\
\text { agriculture, } \\
\text { Damodaran) }\end{array}$ & 0,74 & industry $B$ & $\begin{array}{l}\text { Farming and } \\
\text { agriculture beta } \\
\text { (Europe) [25] }\end{array}$ & $\begin{array}{c}\text { RFR+EPR* companyB } \\
+ \text { SCP+SCRP }\end{array}$ & 14,0138 \\
\hline $\begin{array}{l}\text { Company beta } \\
\text { (monthly) }\end{array}$ & 0,48 & company B & & $\begin{array}{c}\text { RFR+EPR* companyB } \\
+ \text { SCP+SCRP }\end{array}$ & 9,7576 \\
\hline $\begin{array}{c}\text { Company beta } \\
\text { (weekly) }\end{array}$ & 0,56 & company B & & $\begin{array}{c}\text { RFR+EPR*companyB } \\
+ \text { SCP+SCRP }\end{array}$ & 11,0672 \\
\hline $\begin{array}{l}\text { Company beta } \\
\text { calculated with } \\
\text { NODERFELASE } \\
\text { method }\end{array}$ & 1,22 & company $B$ & & $\begin{array}{c}\text { RFR+EPR*companyB } \\
+ \text { SCP+SCRP }\end{array}$ & 21,8714 \\
\hline $\begin{array}{l}\text { Size premium } \\
\text { (small company } \\
\text { premium) }\end{array}$ & 0 & SCP & $\begin{array}{l}\text { Used only for small } \\
\text { companies }\end{array}$ & & \\
\hline $\begin{array}{c}\text { Specific } \\
\text { company risk } \\
\text { premium }\end{array}$ & 0 & SCRP & $\begin{array}{l}\text { We take the value } \\
\text { to be zero, because } \\
\text { in this article we } \\
\text { study the influence } \\
\text { of another factor }\end{array}$ & & \\
\hline
\end{tabular}

* industry beta we changed for company beta according to [15].

Source: Own elaboration.

Table 4. Calculation of a share value of Astarta Holding N.V.*

\begin{tabular}{|c|c|c|c|c|c|c|}
\hline $\begin{array}{l}\text { Operating cash } \\
\text { flows, prognosis, } \\
2019-2023 \text { years, } \\
\text { th. EUR }\end{array}$ & 46000,00 & 48300,00 & 50715,00 & 53250,75 & 55913,29 & $\begin{array}{c}\text { Post-forecast } \\
\text { period }\end{array}$ \\
\hline & 0,5 & 1,5 & 2,5 & 3,5 & 4,5 & \\
\hline Years & 1 & 2 & 3 & 4 & 5 & \\
\hline $\begin{array}{l}\text { Cash flows, } \\
\text { th. EUR }\end{array}$ & 48092,05 & 50496,66 & 53021,49 & 55672,56 & 5055,17 & \\
\hline Discount rate & $21,87 \%$ & $21,87 \%$ & $21,87 \%$ & $21,87 \%$ & $21,87 \%$ & $21,87 \%$ \\
\hline Present value & 0,90584021 & 0,743284 & 0,6098991 & 0,50045054 & 0,4106429 & 0,371976877 \\
\hline $\begin{array}{l}\text { Net present val- } \\
\text { ue, th. EUR }\end{array}$ & 43563,72 & 37533,36 & 32337,76 & 27861,37 & 2075,87 & 143372,069 \\
\hline $\begin{array}{l}\text { Reversion value, } \\
\text { th. EUR }\end{array}$ & & & & & & 23114,650 \\
\hline $\begin{array}{l}\text { Company value, } \\
\text { th. EUR }\end{array}$ & & & & & & 151970,184 \\
\hline $\begin{array}{l}\text { Shares outstand- } \\
\text { ing }\end{array}$ & & & & & & 25000000 \\
\hline Share value, EUR & & & & & & 6,08 \\
\hline
\end{tabular}

* valuation date 01.07.2019 p.

Source: Own elaboration based on [15]. 
Astarta Holding N.V. company value calculation using an income approach, discounted cash flow method at discount rates: $11,07 \%$; $9,76 \%$ and $14,01 \%$, obtained with using of other company betas (see Table 3 ) is carried out similarly to the Table 4.

In a Table 5 we can compare company values and values of one share, obtained using different company betas.

Table 5. Astarta Holding N.V. company betas and their impact on the value of one share

\begin{tabular}{|l|c|c|c|c|}
\cline { 2 - 4 } \multicolumn{1}{c|}{} & $\begin{array}{c}\text { Company beta } \\
\text { (monthly) }\end{array}$ & $\begin{array}{c}\text { Company beta } \\
\text { (weekly) }\end{array}$ & $\begin{array}{c}\text { Company beta } \\
\text { calculated with } \\
\text { NODERFELASE method }\end{array}$ & $\begin{array}{c}\text { Industry beta } \\
\text { (Farming and } \\
\text { agriculture, } \\
\text { Damodaran) }\end{array}$ \\
\cline { 2 - 5 } & 0,48 & 0,56 & 1,22 & 0,74 \\
\hline $\begin{array}{l}\text { Discount rate, } \\
\text { calculated with } \\
\text { this beta }\end{array}$ & 9,76 & 11,07 & 21,87 & 14,01 \\
\hline $\begin{array}{l}\text { Company value, } \\
\text { calculated with } \\
\text { this beta, EUR }\end{array}$ & 207750000 & 198250000 & 152000000 & 781500000 \\
\hline $\begin{array}{l}\text { Share value, } \\
\text { calculated with } \\
\text { this beta, EUR }\end{array}$ & 8,31 & 7,93 & 6,08 & 30,91 \\
\hline $\begin{array}{l}\text { Share value, } \\
\text { calculated with } \\
\text { this beta, PLN }\end{array}$ & 35,38 & 33,37 & 25,89 & \\
\hline $\begin{array}{l}\text { Last quotations on } \\
\text { valuation date* } \\
\text { (Warsaw stock } \\
\text { exchange), PLN }\end{array}$ & 24,40 & \multicolumn{2}{|}{} \\
\hline
\end{tabular}

* date of valuation 01.07.2019 p.

Source: Own elaboration.

According to the results of Table 5: the NODERFELASE method, that is a method of company beta (individual beta) calculation, gives the result of the value of one share closer to its current quotations on the Warsaw Stock Exchange, compared to beta coeffi- cients, based on historical market data and pre-calculated betas provided by different investment services.

We calculated discount rates (Table 6) using the different company betas for IMC S.A., obtained by us from the above calculations.

Table 6. IMC S.A. discount rates calculation using different company betas

\begin{tabular}{|c|c|c|c|c|c|}
\hline Parameter & 2019 & Abbreviation & Comments & Formula* & Discount rate \\
\hline Risk free rate & 1,9 & RFR & $\begin{array}{l}\text { The average rate on } \\
\text { deposits of legal entities } \\
\text { in foreign currency in } \\
\text { Ukraine } 5,5 \% \text { [23] } \\
\text { Inflation rate (2019) } \\
3,6 \% \text { [24] }\end{array}$ & & \\
\hline $\begin{array}{l}\text { Equity risk } \\
\text { premium }\end{array}$ & 16,37 & ERP & $\begin{array}{l}\text { The average equity risk } \\
\text { premium for Ukraine } \\
\text { (Damodaran) [25] }\end{array}$ & & \\
\hline $\begin{array}{l}\text { Industry beta } \\
\text { (Farming and } \\
\text { agriculture, } \\
\text { Damodaran) }\end{array}$ & 0,74 & industry $B$ & $\begin{array}{l}\text { Farming and agriculture } \\
\text { beta (Europe) [25] }\end{array}$ & $\begin{array}{l}\text { RFR+EPR*companyB } \\
+ \text { SCP+SCRP }\end{array}$ & 14,0138 \\
\hline
\end{tabular}


continuation table 6

\begin{tabular}{|c|c|c|c|c|c|}
\hline $\begin{array}{c}\text { Company beta } \\
\text { (monthly) }\end{array}$ & 0,12 & company B & & $\begin{array}{l}\text { RFR+EPR* company } B \\
+ \text { SCP+SCRP }\end{array}$ & 3,8644 \\
\hline $\begin{array}{l}\text { Company beta } \\
\text { (weekly) }\end{array}$ & 0,13 & company B & & $\begin{array}{l}\text { RFR+EPR* company } B \\
+ \text { SCP+SCRP }\end{array}$ & 4,0281 \\
\hline $\begin{array}{l}\text { Company beta } \\
\text { calculated } \\
\text { with } \\
\text { NODERFELASE } \\
\text { method }\end{array}$ & 1,765 & company B & & $\begin{array}{l}\text { RFR+EPR*companyB } \\
+ \text { SCP+SCRP }\end{array}$ & 30,79 \\
\hline $\begin{array}{l}\text { Size premium } \\
\text { (small } \\
\text { company } \\
\text { premium) }\end{array}$ & 0 & SCP & $\begin{array}{l}\text { Used only for small } \\
\text { companies }\end{array}$ & & \\
\hline $\begin{array}{c}\text { Specific } \\
\text { company risk } \\
\text { premium }\end{array}$ & 0 & SCRP & $\begin{array}{l}\text { We take the value to be } \\
\text { zero, because in this } \\
\text { article we study the } \\
\text { influence of another } \\
\text { factor }\end{array}$ & & \\
\hline
\end{tabular}

*industry beta we changed for company beta according to [15]

Source: Own elaboration.

Further, we calculated the company value of IMC S.A. using an income approach, discounted cash flow method (see Table 7) at a discount rate - $30,79 \%$. The cash flow fore-

cast is based on the simple average value of the operating cash flow over the past 5 years (2014-2018) with a 5\% annual growth rate.

Table 7. Calculation of a share value of IMC S.A.*

\begin{tabular}{|c|c|c|c|c|c|c|}
\hline $\begin{array}{l}\text { Operating } \\
\text { cash flows, } \\
\text { prognosis, } \\
2019-2023 \\
\text { years, th. } \\
\text { EUR. }\end{array}$ & 51566,00 & 54144,30 & 56851,52 & 59694,09 & 62678,80 & $\begin{array}{l}\text { Post-forecast } \\
\text { period }\end{array}$ \\
\hline & 0,5 & 1,5 & 2,5 & 3,5 & 4,5 & \\
\hline Years & 1 & 2 & 3 & 4 & 5 & \\
\hline $\begin{array}{l}\text { Cash flows, } \\
\text { th. EUR }\end{array}$ & 52985,83 & 55635,12 & 58416,88 & 61337,72 & 28162,53 & \\
\hline $\begin{array}{l}\text { Discount } \\
\text { rate }\end{array}$ & $30,79 \%$ & $30,79 \%$ & $30,79 \%$ & $30,79 \%$ & $30,79 \%$ & $30,79 \%$ \\
\hline $\begin{array}{l}\text { Present } \\
\text { value }\end{array}$ & 0,874405197 & 0,668556615 & 0,511167991 & 0,390831096 & 0,298823378 & 0,261292715 \\
\hline $\begin{array}{l}\text { Net pre- } \\
\text { sent value, } \\
\text { th. EUR }\end{array}$ & 46331,09 & 37195,23 & 29860,84 & 23972,69 & 8415,62 & 145775,464 \\
\hline $\begin{array}{l}\text { Reversion } \\
\text { value, } \\
\text { th. EUR }\end{array}$ & & & & & & 91466,474 \\
\hline $\begin{array}{l}\text { Company } \\
\text { value, } \\
\text { th. EUR }\end{array}$ & & & & & & 169674,988 \\
\hline $\begin{array}{l}\text { Shares out- } \\
\text { standing }\end{array}$ & & & & & & 33178000,0 \\
\hline $\begin{array}{l}\text { Share } \\
\text { value, EUR }\end{array}$ & & & & & & 5,11 \\
\hline
\end{tabular}

*valuation date 01.07.2019.

Source: Own elaboration based on [15].

IMC S.A. company value calculation using an income approach, discounted cash flow method at discount rates: $14,01 \%, 4,03 \%$ and

$3,86 \%$, obtained with using of other company betas (see Table 6) is carried out similarly to the Table 7. 
In a Table 8 we can compare company valdifferent company betas. ues and values of one share, obtained using

Table 8. IMC S.A company betas and their impact on the value of one share

\begin{tabular}{l|c|c|c|c|}
\cline { 2 - 5 } \multicolumn{1}{c|}{} & $\begin{array}{c}\text { Company beta } \\
\text { (monthly) }\end{array}$ & $\begin{array}{c}\text { Company beta } \\
\text { (weekly) }\end{array}$ & $\begin{array}{c}\text { Company beta } \\
\text { calculated with } \\
\text { NODERFELASE } \\
\text { method }\end{array}$ & $\begin{array}{c}\text { Industry beta } \\
\text { (Farming and } \\
\text { agriculture, } \\
\text { Damodaran) }\end{array}$ \\
\cline { 2 - 5 } & 0,12 & 0,13 & 1,44 & 0,74 \\
\hline $\begin{array}{l}\text { Discount rate, } \\
\text { calculated with } \\
\text { this beta }\end{array}$ & 3,86 & 4,03 & 30,79 & 14,01 \\
\hline $\begin{array}{l}\text { Company value, } \\
\text { calculated with } \\
\text { this beta, EUR }\end{array}$ & 838739840 & 807884300 & 193427740 & 296279540 \\
\hline $\begin{array}{l}\text { Share value, } \\
\text { calculated with } \\
\text { this beta, EUR }\end{array}$ & 25,28 & 24,35 & 5,11 & 8,93 \\
\hline $\begin{array}{l}\text { Share value, } \\
\text { calculated with } \\
\text { this beta, PLN }\end{array}$ & 107,63 & 103,67 & 22,32 & 38,02 \\
\hline $\begin{array}{l}\text { Last quotations } \\
\text { on valuation } \\
\text { date* (Warsaw } \\
\text { stock } \\
\text { exchange) , PLN }\end{array}$ & 16,40 & \multicolumn{3}{|l}{} \\
\hline
\end{tabular}

Source: Own elaboration.

According to the results of Table 8: the NODERFELASE method, that is a method of company beta (individual beta) calculation, gives the result of the value of one share closer to its current quotations on the Warsaw Stock Exchange, compared to beta coefficients based on historical market data and pre-calculated betas, provided by different investment services.

Conclusions. The most controversial issue in agricultural business valuation with discounted cash flow method is calculation of the discount rate. After all, the magnitude of this coefficient has a significant impact on the results of business valuation.

Our calculations confirm the instability of beta, calculated on the basis of historical data, it dependence on data collection period, market indicator taken as a benchmark, in-

\section{Список бібліографічних посилань}

1. Sharpe W. F. Capital asset prices: A theory of market equilibrium under conditions of risk. The Journal of Finance. 1964. Vol. 19. № 3. P. 425-442. DOI: https://doi.org/10.1111/ j.1540-6261.1964. tb02865.x.

2. Cea J. Modelos de comportamiento de la gran empresa. Madrid : Ministerio de Hacienda.: Instituto de Planificación Contable, D.L., 1979. 955 p.

3. Caballer-Mellado V., Moya-Clemente I. Valoración bursátil de empresas agroalimentarias. Invest Agrar: Econ. 1998. № 9. C. 319-344. vestment service which provides precalculated beta coefficients.

Given research revealed that the NODERFELASE method provides the most correct result in calculation of beta coefficient of agricultural companies during realization the procedure of business valuation. The obtained results of one share value (using NODERFELASE method for company beta calculation) is closer to its current quotations on the Warsaw Stock Exchange, compared to beta coefficients, based on historical market data and pre-calculated betas, provided by different investment services. Further researches of this issue should be aimed at verifying the correctness of other methods of beta coefficient calculation in agricultural business valuation for investment purposes.

\section{References}

1. Sharpe, W.F. (1964). Capital asset prices: A theory of market equilibrium under conditions of risk. The Journal of Finance, 19 (3), pp. 425-442 [In English].

2. Cea, J.L. (1979). Modelos de comportamiento de la gran empresa. Madrid: Ministerio de Hacienda. Instituto de Planificación Contable, D.L. [In Spanish].

3. Caballer-Mellado, V. \& Moya-Clemente, I. (1998). Valoración bursátil de empresas agroalimentarias. Invest Agrar: Econ, 9 (3), pp. 319-344 [In Spanish]. 
4. Tabak D. A CAPM-Based Approach to Calculating IIliquidity Discounts. NERA Economic Consulting. 2002. URL : https://www.nera.com/content/dam/nera/publications/archiv e1/5657.pdf. [in English].

5. Holton, Glyn A. Defining Risk. Financial Analyst Journal. 2004. № 60. C. 19-25.

6. Fernandez $P$. Métodos de valoración de empresas. IESE Business School, Documento de Investigación DI-771. 2008. URL : https://media.iese.edu/research/pdfs/DI-0771.pdf.

7. Коваль Н. В. Обґрунтування величини дисконтної ставки для розрахунку прогнозної ефективності інвестиційних проектів в Україні. Інвестиції: практика та досвід. 2010. № 9. С. 9-13.

8. Колчар Ю. О. Методичний підхід до визначення ставки дисконтування для оцінки нематеріальних активів банку у межах доходного підходу. Регіональна економіка. 2013. № 3. С. 123-129.

9. Ралко О. С. Методи визначення ставки дисконтування. Науковий вісник Міжнародного гуманітарного універcumemy. 2015. № 11. C. 150-153.

10. Fernandez P., Pershin V., Fernández Acín I. Discount Rate (Risk-Free Rate and Market Risk Premium) Used for 41 Countries in 2017: A Survey. IESE Business School, Documento de Investigación DI-771. 2017. URL : http://www.valumonics.com/ wp-content/uploads/2017/06/Discount-rate-Pablo-Fern\%C3\%A1ndez. pdf. DOI: http://dx.doi.org/10.2139/ssrn.2954142.

11. Fernandez $P$. Company Valuation Methods: The Most Common Errors in Valuations. Working Paper №449 IESE. 2004. URL : https://notendur.hi.is/ajonsson/kennsla2006/Valuation.pdf.

12. Orsinger R. R. Business Valuation Upon Divorce: How Theory and Practice Can Lead to Problems In Court. AICPA/AAML. Conference on divorce, May 10-12, 2012. Las Vegas, NV (USA). 2012. URL : http://www.orsinger.com/ PDFFiles/BusinessValuationUponDivorce.pdf.

13. Fernandez $P$. The equity premium in 100 textbooks. IESE Business School. Working. 2009. Paper № 829. URL : https://doi.org/10.2139/ssrn.1148373. DOI: https://doi.org/ 10.2139/ssrn.1148373.

14. Chincarini L. B., Kim D., Moneta F. Beta and Firm Age. 2019. URL : http://dx.doi.org/10.2139/ssrn.2821852.

15. Fernández, P. Carabias, Jose M. El Peligro de utilizar Betas Calculadas. Documento de investigación. 2007. № 685. URL : https://core.ac.uk/download/pdf/6536319.pdf.

16. Fama E. F. \&, MacBeth J. D. Risk, Return, and Equilibrium: Empirical Tests". Journal of Political Economy. 1973. № 81. C. 607-636. DOI: https://doi.org/10.1086/260061.

17. Hollstein F., Prokopczuk M. Estimating Beta. Journal of Financial and Quantitative Analysis. 2016. № 51. C. 1437-1466. DOI: $10.1017 /$ S0022109016000508.

18. S\&P Global Agribusiness Index. S\&P Dow Jones indices website. 2019. URL : https://us.spindices.com/indices/ equity/sp-global-agribusiness-equity-index.

19. The official website of Warsaw stock exchange. Warsaw stock exchange. 2019. URL : https://www.gpw.pl/en-home.

20. Сівіцька Ю. О. Оцінка сільськогосподарського підприємства для інвестиційних цілей: методологічний аспект. Modern Economics. 2019. № 15. C. 175. DOI: https://doi.org/10.31521/modecon.V15(2019)-25.

21. The official website of IMC S.A. Financial reports. 2019. URL : http://imcagro.com.ua/ua/dlya-investorov/financialreports.

22. The official website of Astarta Holding N.V. Financial reports. 2019. URL : https://astartaholding.com/page/36.

23. Вартість строкових депозитів юридичних осіб. міністерство фінансів україни. 2019. URL https://index.minfin.com.ua/banks/deposit/company/.

24. Офіційний рівень інфляції. Міністерство фінансів України. 2019. URL : https://index.minfin.com.ua/economy/ index/inflation/.

25. Country Default Spreads and Risk Premiums. The official website of Leonard N. Stern School of Business. 2019. URL : http://pages.stern.nyu.edu/ adamodar/New_Home_Page/ datafile/ctryprem.html.
4. Tabak, D. (2002). A CAPM-based approach to calculating illiquidity discounts. NERA Economic Consulting Working Paper. Retrieved from: https://www.nera.com/content/dam/ nera/publications/archive1/5657.pdf [In English].

5. Holton, G.A. (2004). Defining risk. Financial Analyst Journal, 60, pp. 19-25 [In English].

6. Fernandez, P. (2008). Métodos de valoración de empresas. IESE Business School, Documento de Investigación DI-771. Retrieved from: https://media.iese.edu/research/pdfs/DI0771.pdf [In Spanish].

7. Koval, N.V. (2010). Obgruntuvannia velychyny dyskontnoi stavky dlia rozrakhunku prohnoznoi efektyvnosti investytsinykh proektiv $v$ Ukraini [Substantiation of the value of the discount rate for calculating the predictive efficiency of investment projects in Ukraine]. Investytsii: praktyka ta dosvid, 9, pp. 9-13 [In Ukrainian].

8. Kolchar, Yu.O. (2013). Metodychnyi pidkhid do vyznachennia stavky dyskontuvannia dlia otsinky nematerialnykh aktyviv banku u mezhakh dokhodnoho pidkhodu [Methodological approach to the discount rate determination for the bank's intangible assets valuation within the income approach]. Rehionalna ekonomika, 3, pp. 123-129 [In Ukrainian].

9. Ralko, O.S. (2015). Metody vyznachennia stavky dyskontuvannia [Methods for determining the discount rate]. Naukovyi visnyk Mizhnarodnoho humanitarnoho universytetu, 11, pp. 150-153 [In Ukrainian].

10. Fernandez, P., Pershin, V., \& Fernández, A.I. (2017). Discount rate (risk-free rate and market risk premium) used for 41 countries in 2017: a survey. IESE Business School. Retrieved from: http://www.valumonics.com/wp-content/ uploads/2017/06/Discount-rate-Pablo-Fern\%C3\%A1ndez.pdf [In English].

11. Fernandez, P. (2004). Company valuation methods: the most common errors in valuations. Working Paper No. 449 IESE. Retrieved from: https://notendur.hi.is/ajonsson/kennsla2006/ Valuation.pdf [In English].

12. Orsinger, R.R. (2012). Business valuation upon divorce: how theory and practice can lead to problems in court. AICPA/AAML. Conference on divorce, May 10-12, 2012. Las Vegas, NV (USA), pp. 1-102. Retrieved from: http://www.orsinger.com/PDFFiles/BusinessValuationUponDivo rce.pdf [In English].

13. Fernandez, P. (2009). The equity premium in 100 textbooks. IESE Business School. Working Paper No. 829. Retrieved from: https: //doi.org/10.2139/ssrn.1148373_[In English].

14. Chincarini, L.B., Kim, D., \& Moneta, F. (2019). Beta and firm age. Retrieved from: http://dx.doi.org/10.2139/ ssrn.2821852 [In English].

15. Fernandez, P. \& Carabias, J.M. (2007). El peligro de utilizar betas calculadas. Documento de investigación № 685 . Retrieved from https: / /ssrn.com/abstract $=897700$ [In Spanish].

16. Fama, E.F. \& MacBeth, J.D. (1973). Risk, return, and equilibrium: empirical tests. Journal of Political Economy, 81, pp. 607-636 [In English].

17. Hollstein, F. \& Prokopczuk, M. (2016). Estimating beta. Journal of Financial and Quantitative Analysis, 51 (4), pp. 1437-1466 [In English].

18. S\&P Global Agribusiness Index. (2019). S\&P Dow Jones indices website. Retrieved from: https://us.spindices.com/ indices/equity/sp-global-agribusiness-equity-index [In English].

19. The official website of Warsaw stock exchange. Retrieved from: https://www.gpw.pl/en-home [In English].

20. Sivitska, Y. (2019). Otsinka silskohospodarskoho pidpryiemstva dlia investytsiinykh tsilei: metodolohichnyi aspekt [Valuing agricultural enterprise for investment purposes: methodological aspect]. Modern Economics, 15 (2019), pp. 175-182 [In Ukrainian].

21. Financial reports. (2019). The official website of IMC S.A. Retrieved from: http://imcagro.com.ua/ua/dlyainvestorov/financial-reports [In English].

22. Financial reports. (2019). The official website of Astarta Holding N.V. Retrieved from: https://astartaholding.com/ page/36 [In English].

23. Vartist strokovykh depozytiv yurydychnykh osib [The cost of term deposits of legal entities]. (2019). Ministerstvo Finansiv Ukrainy. Retrieved from: https://index.minfin.com.ua/ banks/deposit/company_[In Ukrainian]. 
24. Ofitsinyi riven infliatsii [The official rate of inflation]. (2019). Ministerstvo Finansiv Ukrainy. Retrieved from: https://index.minfin.com.ua/economy/index/inflation [In Ukrainian].

25. Country default spreads and risk premiums. (2019). The official website of Leonard N. Stern School of Business. Retrieved from: http://pages.stern.nyu.edu/ adamodar/ New_Home_Page/datafile/ctryprem.html_[In English].

\section{Сівіцька Ю.О. Специфіка застосування ставки дисконтування для оцінки вартості аграрного бізнесу}

Meта статmi - визначити та обгрунтувати який з методів обчислення beta коефіцієнта сільськогосподарських компаній для розрахунку ставки дисконтування модифікованим методом кумулятивної побудови дає найбільш коректний результат. Виявити особливості, проблемні питання та шляхи їх вирішення, що виникають при обчисленні ставки дисконтування сільськогосподарських компаній у процесі виконання процедури оцінки вартості бізнесу.

Методика дослідження. Дослідження проведено на прикладі агрохолдингів IMC S.A. ma Astarta Holding N.V., акції яких котируються на Варшавській фондовій біржі (WSE). Обчислено bеtа коефіцієнти цих агрохолдингів за різними методиками та використано їх для визначення вартості сільськогосподарського бізнесу за дохідним методологічним підходом, методом дисконтованих грошових потоків.

Результати дослідження. Доведено необхідність обчислення коефіцієнта company beta замість застосування вже розрахованих у різних джерелах коефіцієнтів industry beta у процесі оцінки вартості сільськогосподарського бізнесу з метою інвестування. Отримані результати свідчать про те, що методологія, обгрунтована в статті, забезпечує оцінку вартості однієї акції компанії, найбільш близьку до їі поточного котирування на Варшавській фондовій біржі.

Елементи наукової новизни. Набуло подальшого розвитку положення про те, що використання готових розрахованих beta коефіцієнтів призводить до викривлення результату оцінки вартості бізнесу. Вперше у статті наведено обґрунтування калькуляції всіх компонентів формули Build-up method modified для обчислення ставки дисконтування сільськогосподарських компаній в процесі оцінки вартості їхнього бізнесу з метою інвестування.

Практична значущість. Результати дослідження будуть корисні фахівцям з оцінки (професійним оцінювачам) у процесі розрахунку ставки дисконтування з метою оцінки сільськогосподарського бізнесу для інвестиційних цілей. Табл.: 8. Puc.: 8. Бібліогр.: 25 .

Ключові слова: ставка дисконтування; бета компанії; оцінка бізнесу; безризикова ставка; премія за ризик власного капіталу; модифікований метод кумулятивної побудови.

Сівіцька Юлія Олександрівна - здобувач ступеня доктора філософії, кафедра підприємництва і права, Полтавська державна аграрна академія (м. Полтава, вул. Сковороди, 1/3)

E-mail: ijosjo@ukr.net

ORCID iD https://orcid.org/0000-0001-8635-9038

\section{Сивицкая Ю.А. Специфика применения ставки дисконтирования для оценки стоимости аграрного бизнеса}

Цель статьи - определить и обосновать какой из методов исчисления beta коэффициента сельскохозяйственных компаний для расчета ставки дисконтирования модифицированным методом кумулятивного построения дает наиболее корректный результат. Выявить особенности, проблемные вопросы и пути их решения, возникающие при расчете ставки дисконтирования сельскохозяйственных компаний в процессе выполнения процедуры оценки стоимости бизнеса.

Методика исследования. Исследование проведено на примере агрохолдингов IMC S.A. и Astarta Holding N.V., акции которых котируются на Варшавской фондовой бирже (WSE). Рассчитаны bеtа коэффициенты этих агрохолдингов с помощью разных методик и применены для определения стоимости сельскохозяйственного бизнеса доходным методологическим подходом, методом дисконтированных денежных потоков.

Результаты исследования. Доказана необходимость вычисления коэффициента company beta вместо применения уже рассчитанных в разных источниках коэффициентов industry beta в процессе оценки стоимости сельскохозяйственного бизнеса с целью инвестирования. Полученные результаты свидетельствуют о том, что методология, обоснованная в статье, обеспечивает оценку стоимости одной акции компании, наиболее близкую к ее текущей котировке на Варшавской фондовой бирже.

Элементы научной новизны. Получило дальнейшее развитие положение о том, что использование готовых рассчи танных bеtа коэффициентов приводит к искажению результата оценки стоимости бизнеса. Впервые в статье приведено обоснование калькуляции всех компонентов формулы Build-up method modified для вычисления ставки дисконтирования сельскохозяйственных компаний в процессе оценки стоимости их бизнеса с целью инвестирования.

Практическая значимость. Результаты исследования будут полезны специалистам по оценке (профессиональным оценщикам) в процессе расчёта ставки дисконтирования для оценки сельскохозяйственного бизнеса для инвестиционных целей. Табл.: 8. Илл.: 8. Библиогр.: 25.

Ключевые слова: ставка дисконтирования; бета компании; оценка бизнеса; безрисковая ставка; премия за риск собственного капитала; модифицированный метод кумулятивного построения.

Сивицкая Юлия Александровна - соискатель степени доктора философии, кафедра предпринимательства и права, Полтавская государственная аграрная академия (г. Полтава, ул. Сковороды, 1/3)

E-mail: ijosjo@ukr.net

ORCID iD https://orcid.org/0000-0001-8635-9038

The article has been received 08.12.2019

Revision: 16.12.2019

Бібліографічний опис для цитування:

Sivitska Yu. O. Specificity of the discount rate application for agricultural business valuation. Економіка АПК. 2019. № 12. С. 97 - 111. 